\title{
Restricted gene flow across fragmented populations of Legrandia concinna, a threatened Myrtaceae endemic to south-central Chile
}

\author{
Flujo génico restringido en poblaciones fragmentadas de Legrandia concinna, una Myrtaceae \\ amenazada endémica del centro-sur de Chile
}

\author{
Camila Martínez Araneda ${ }^{\text {a,b }}$, Andrea C Premolic*, Cristian Echeverría ${ }^{\text {d, }}$ Philip Thomas $^{\text {b }}$ \\ Paulina Hechenleitner ${ }^{\text {a,b }}$ \\ a Universidad Austral de Chile, Valdivia, Chile. \\ ${ }^{\mathrm{b}}$ Royal Botanic Garden Edinburgh, Scotland. \\ *Corresponding author: ' Universidad Nacional del Comahue, INIBIOMA CONICET, Quintral 1250, 8400 Bariloche, Argentina, \\ phone/fax: 54-2944-422111, apremoli@crub.uncoma.edu.ar \\ ¿ U niversidad de Concepción, Facultad de Ciencias Forestales, Concepción, Chile.
}

\begin{abstract}
SUMMARY
The objective of the present study was to analyze levels and distribution patterns of isozyme variation in the only five known populations of Legrandia concinna, a threatened and range-restricted species to the temperate forest of the Chilean South Central Andes. Six enzyme systems were resolved using a combination of two buffer solutions which yielded information on nine putative loci; $67 \%$ of these were polymorphic in at least one population. Levels of genetic variation for $L$. concinna populations are low, with average polymorphism of $31 \%$, and observed and expected heterozygosis of 0.07 and 0.11 respectively. We found significant mean within-population inbreeding $\left(F_{\mathrm{IS}}=0.395\right)$ and among-population divergence $\left(F_{\mathrm{ST}}=41 \%\right)$. Cluster analysis indicates that genetic diversity is latitudinally structured. Our results show that even small populations may still retain as much genetic diversity as larger ones, which, in addition to significant restrictions for gene flow, call for urgent conservation actions; otherwise L. concinna could be seriously threatened.
\end{abstract}

Key words: isozyme, rare species, restricted gene flow, vulnerable species.

\section{RESUMEN}

El objetivo de este estudio fue analizar los niveles y patrones de distribución de polimorfismos isoenzimáticos en las únicas cinco poblaciones conocidas de Legrandia concinna, una especie amenazada de rango restringido de los bosques templados de Los Andes de Chile central. Seis sistemas enzimáticos se resolvieron usando una combinación de dos soluciones tampón que dieron información sobre nueve loci génicos putativos, $67 \%$ de los cuales resultaron polimórficos en al menos una población. Los niveles de variación genética en poblaciones de L. concinna resultaron bajos, con un polimorfismo promedio de $31 \%$ y heterocigosis observada y esperada de 0,07 y 0,11 , respectivamente. Las poblaciones de $L$. concinna mostraron una significativa endogamia dentro de las poblaciones $\left(F_{\mathrm{IS}}=0,395\right)$ y divergencia entre poblaciones $\left(F_{\mathrm{ST}}=41 \%\right)$. El análisis multivariado de cluster indicó que la diversidad genética está estructurada latitudinalmente. Los resultados sugieren que aún poblaciones pequeñas pueden retener tanta diversidad genética como las de mayor tamaño. Esto, en combinación con las restricciones significativas al flujo génico, muestra la necesidad de realizar medidas urgentes de conservación, de lo contrario L. concinna se encontrará seriamente amenazada.

Palabras clave: isoenzimas, especie rara, flujo génico restringido, especie vulnerable.

\section{INTRODUCTION}

Threatened species typically have small and declining populations which suffer from the effects of inbreeding and loss of genetic diversity. Whereas inbreeding reduces reproduction and survival, the loss of genetic variation decreases the ability of populations to cope with environmental change (Brook et al. 2002, Frankham et al. 2002). Decreased heterozygosity characterizes populations of threatened species which are prone to suffer from local extinction caused by genetic factors (Spielman et al. 2004).
The original forest cover in south central Chile has been dramatically reduced. For example, in the coastal range of the Maule Region (between $35^{\circ} 16^{\prime}$ and $36^{\circ} 41^{\prime}$ S) native forests have declined $64 \%$ in the last 30 years (Echeverría et al. 2006). In the Andean Range of the same region, there was a reduction in native forest cover of $44 \%$ (Altamirano and Lara 2010). Within this region large areas either have been converted for agriculture or cleared and then afforested with exotic species such as Pinus radiata D. Don. and Eucalyptus species. As a result, no continuous native forest fragments larger than 5,000 ha exist in south- 
central Chile (Neira et al. 2002). Although this area contains $77 \%$ of threatened plant species (Armesto et al. 1992), its representation within conservation areas is only $0.6 \%$ of the total protected area in the whole country. The high number of threatened species, the scant representation in the protected area system, and the increasing threat of the remaining forest mean that conservation actions in central Chile are urgently needed.

Temperate forests of central Chile located between the Maule river $\left(35^{\circ} \mathrm{S}\right)$ and Chiloé Island $\left(43^{\circ} \mathrm{S}\right)$ contain high levels of endemism including 1,600 species, 28 endemic genera, and two monotypic families (Myers et al. 2000). This is the result of geographical influences and historical factors. Natural barriers such as the Andes Mountains in the east, the Atacama Desert in the north, and the Pacific Ocean in the west, isolate the Chilean flora from the rest of temperate and tropical forests in South America. Thus, this forest is considered a biogeographic island (Armesto et al. 1995). Additionally, glaciations during the Pleistocene have isolated populations both in the Andes and the Coastal range, with the result that many endemic species and genera have disjunct or localized distributions (Donoso 1993, Villagrán and Le-Quesne 1996). The effect of glaciations has been the focus of biogeographical studies and genetic evidence suggests that tree species from southern Chile and Argentina were able to survive in multiple refugia (Premoli et al. 2000, Bekessy et al. 2002, Torres-Díaz et al. 2007). However, limited information exists on woody species inhabiting northern latitudes of central Chile.

Legrandia concinna (Phil.) Kausel (Myrtaceae), common name luma del norte or luma blanca, is a monotypic genus that consists of five isolated populations distributed from Curicó to Ñuble in central Chile (35 $24^{\circ}$ ' $42^{\prime \prime}$ to $36^{\circ} 41^{\prime} 31.3^{\prime \prime}$ S) within the administrative regions of Maule and Biobío. It can be locally dominant within the roble-hualo (Nothofagus obliqua (Mirb.) Oerst and Nothofagus glauca (Phil.) Krasser) forest type. It often occurs associated with Aextoxicon punctatum Ruiz et Pav., Gevuina avellana Molina, Laurelia sempervirens (Ruiz et Pav.) Tul., Luma apiculata (DC.) Burret, Myrceugenia planipes O. Berg, Persea lingue Nees, and Sophora macrocarpa SM. It is a small, usually multistem evergreen tree, reaching up to $8 \mathrm{~m}$ in height (Landrum 1986). Flowers are solitary, hermaphrodite, and actinomorphic with four white petals. The presence of a pair of bracteoles has led some authorities to suggest that it may be a primitive member of the Myrtaceae (Serra et al. 1986). Fruits are fleshy, containing one to three seeds. They range in size between 1.5 and $2.5 \mathrm{~cm}$ long; which makes them the largest fruit among other Chilean myrtles. The lack of dispersal vectors or appendices (wings or hairs) may account for their limited fruit dispersal. Its fragrant flowers attract several insects, such as bees (Apis mellifera Linneo 1758; Hymenoptera: Apidae) and bumblebees.

Legrandia concinna has been listed as vulnerable within the Red List of Chilean Terrestrial Flora (Benoit 1989) and as rare by the IUCN 1997 Red List of Threatened Plants (Walter and Gillett 1998). Recently Gardner et al. (2006) have assessed this species as Critically Endangered which means it is facing an extreme threat of extinction in the wild. Main threats to L. concinna are related to the increased deforestation rates and loss of natural populations, substitution with exotic timber species, land conversion to agriculture (Serra et al. 1986), and most recently the construction of hydroelectric dams which may put $L$. concinna populations at risk of local extinctions.

The aim of this study is to conduct a preliminary analysis on the levels and distribution patterns of isozyme diversity in all remaining populations of the range-restricted and monotypic $L$. concinna to provide information for the design of conservation practices. Legrandia concinna is currently known from five locations, being the northernmost population geographically disjunct from the rest. We hypothesize that small and isolated populations of L. concinna are remnants of a formerly more continuous range. We expect that fragmented $L$. concinna populations, currently affected by genetic drift and restricted gene flow, will show reduced within-population genetic diversity and significant among-population divergence due to isolation.

\section{METHODS}

Population sampling. All currently known populations of L. concinna were sampled at five locations (figure 1, table 1). Within each population, three samples for herbarium

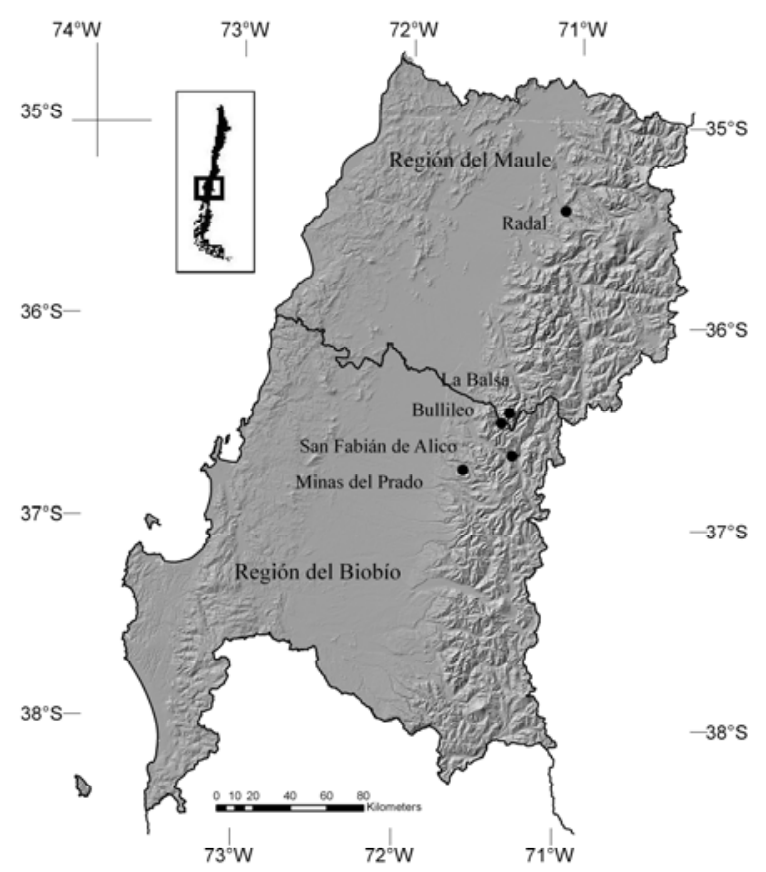

Figure 1. Location of sampled populations of Legrandia concinna.

Mapa de la ubicación de poblaciones de Legrandia concinna. 


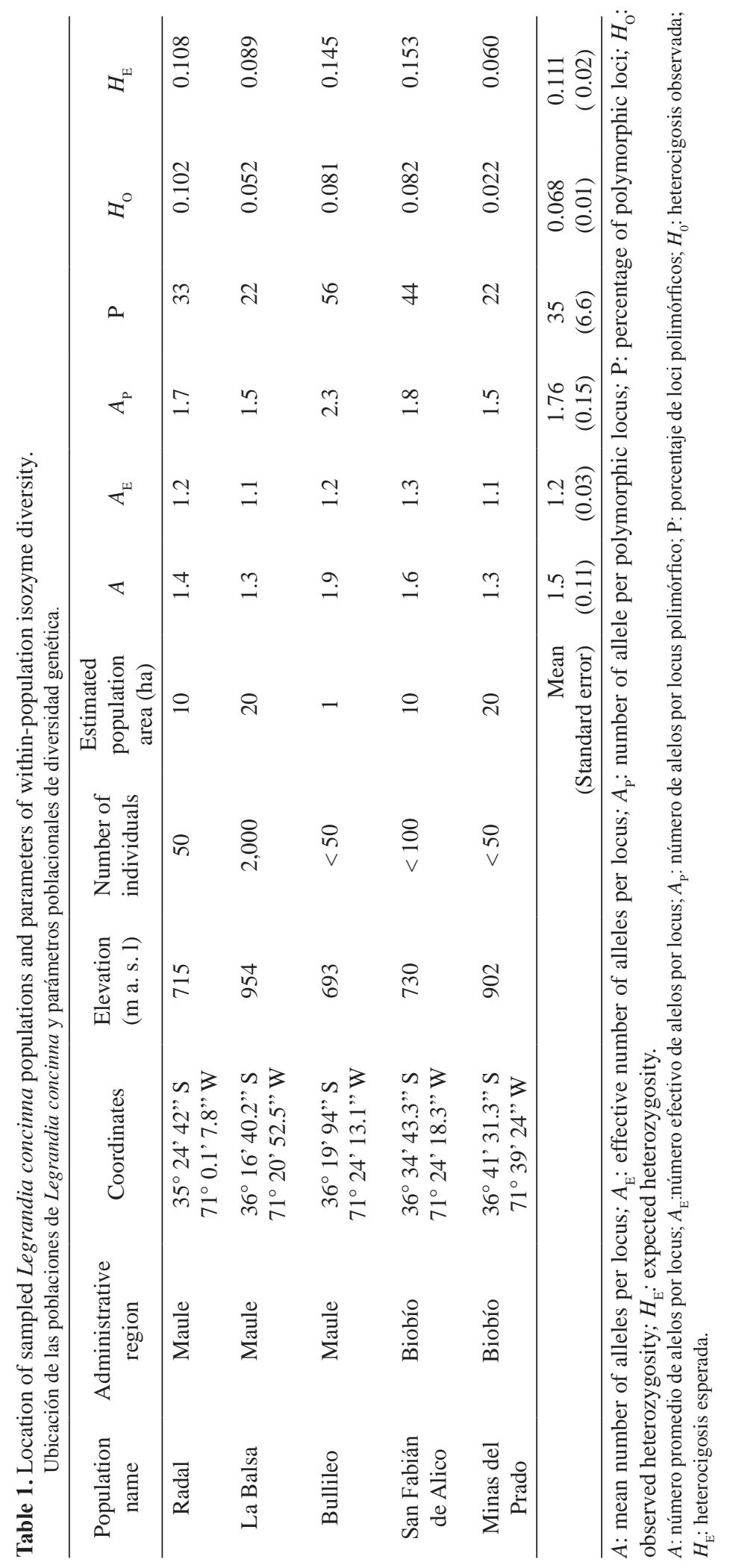


specimens were collected and stored at the Herbarium of Universidad de Concepción, Chile (CONC), Museo de Historia Natural Chile (SGO), and the Royal Botanic Garden Edinburgh (E). Sampling consisted of collection of terminal $10-15 \mathrm{~cm}$-long twigs containing fresh leaf tissue from 30 randomly selected individuals from each population. Individuals were separated by a minimum distance of $10 \mathrm{~m}$ to avoid sampling of spatially clustered similar genotypes. Samples were kept at $0-4{ }^{\circ} \mathrm{C}$ until protein extraction. Once in the laboratory, approximately $1 \mathrm{~g}$ of fresh foliage was ground in mortars using liquid nitrogen, and enzymes were extracted with a buffer following Mitton et al. (1979). Homogenates were stored at $-80{ }^{\circ} \mathrm{C}$ until they were soaked onto filter-paper wicks (Whatman No.3) which were inserted into $12 \%$ weight to volume ratio starch gels. Enzyme extraction and isozyme analyses were conducted at Laboratorio Ecotono, Universidad Nacional del Comahue, Bariloche, Argentina.

Isozyme electrophoresis. Horizontal electrophoresis was conducted using the histidine-tris $\mathrm{pH} 7.0$ buffer system (King and Dancik 1983) and the modified system B by Conkle et al. (1982). Running schedules were constant currents of 40 and $75 \mathrm{~mA}$, respectively, for about $5 \mathrm{~h}$. We preliminarily tested 14 enzymes, and a total of six enzyme systems consistently produced clear and interpretable banding patterns resolving nine putative loci. These were isocitrate dehydrogenase (Idh), malic enzyme (Me-1, Me-2), malate dehydrogenase $(M d h)$, cathodic peroxidase (Perc1, Perc-2), phosphoglucoisomaerase (Pgi-1, Pgi-2), and shikimate dehydrogenase (Skdh). We assumed Mendelian inheritance for all loci, based on banding patterns and the expected enzyme unit substructures. Scoring of isozyme genotypes consisted of assigning consecutive numbers so that the most anodal, i.e. fast, locus and/or allele were designated with the lowest numeral.

Data analysis. Standard measures of genetic diversity were calculated for each population using POPGENE v. 1.31 (Yeh et al. 1997). These included the mean number of alleles per locus $(A)$, the effective number of alleles $\left(A_{\mathrm{E}}\right)$, the mean number of alleles per polymorphic locus $\left(A_{\mathrm{p}}\right)$, the percentage of polymorphic loci (P), and the observed and expected heterozygosity under the Hardy-Weinberg equilibrium ( $H_{\mathrm{O}}$ and $H_{\mathrm{E}}$, respectively). Among all such metrics, $H_{\mathrm{E}}$ is probably the most commonly used index of genetic diversity, which is often referred to as genic diversity for isozyme data. It is a function of the proportion of polymorphic loci, the number of alleles per locus, and the evenness of allele frequencies within populations or species. In contrast, $H_{\mathrm{O}}$ is calculated directly from observed genotype frequencies and therefore is less valuable as a comparative measure of diversity, since it is affected by inbreeding and other evolutionary processes violating the assumptions of Hardy-Weinberg equilibrium (Berg and Hamrick 1997). Therefore, discussions on within-population diversity measures will be based on $H_{\mathrm{E}}$ whereas $H_{\mathrm{O}}$ will be used for inbreeding estimates.

Inbreeding within each population was estimated by fixation indices $F_{\mathrm{IS}}=1-H_{\mathrm{O}} / H_{\mathrm{E}}$. Deviation of genotypic frequencies to Hardy-Weinberg equilibrium and the significance of fixation indices were analyzed by $\chi^{2}$ tests (Li and Horvitz 1953). Population structure was analyzed by total $\left(H_{T}\right)$ and within-population $\left(H_{S}\right)$ genetic diversity using polymorphic loci (Nei 1973). Average inbreeding coefficients were estimated by $F_{\text {IS }}$ that represents the inbreeding due to non-random mating within populations, and $F_{S T}$ due to population subdivision. Means and $95 \%$ confidence intervals were obtained by resampling schemes. To test if genetic partitioning in the range-restricted L. concinna by means of within-population inbreeding $\left(F_{\text {IS }}\right)$ and among-population divergence $\left(F_{S T}\right)$ differed from that in other widespread Myrtaceae such as Luma apiculata, the degree of overlap of $95 \%$ confidence intervals of such parameters was used. This was calculated by means of polymorphic loci using the program FSTAT version 2.9.1 (Goudet 2000) which computes unbiased estimates.

Differentiation among populations was analyzed by Rogers' (1972) genetic distance, because Nei's (1978) genetic distance is nonparametric. The resulting distance matrix was used to build an UPGMA dendrogram. The association between geographic and genetic distances was investigated using Mantel's (1967) generalized regression procedure.

\section{RESULTS}

Six out of a total of nine resolved putative isozyme loci (67 \%) were polymorphic, i.e. having more than one allele, in at least one population. Monomorphic loci were Idh, Perc-2, Pgi-1. Allelic frequencies at all polymorphic loci (Mdh, Me-1, Me-2, Perc-1, Pgi-2, Skdh) were heterogeneous among populations $\left(P<0.05, \chi^{2}\right.$ tests). Populations at the northern and southern range could be identified both, by differences in allele frequencies and by unique alleles, i.e. those present in only one population, as well (table 2, figure 2). Alleles 1 and 3 for Mdh were unique to the northern population Radal. Noteworthy, $M d h$-2 was the most common allele in all analyzed populations except Radal where $M d h-3$ was the most frequently scored allele. Southern population, Bullileo, had the highest number of unique alleles; these were allele 2 at $M e-1$, allele 4 at $P g i-2$, and allele 3 at $S k d h$. Also allele 1 at $S k d h$ was unique to San Fabián de Alico. A number of such unique alleles were also found at low frequencies e.g. 0.017 which represents one out of a total of 60 potential alleles at anyone population. This means that low-frequency alleles hardly occur as homozygous but as heterozygous genotypes instead, which agrees with population genetic theory (Hartl and Clark 2007).

Overall, analyzed $L$. concinna populations had distinct levels of isozyme diversity with no apparent relation with 
Table 2. Allele frequencies at polymorphic loci in populations of Legrandia concinna. Frecuencias alélicas de loci polimórficos en poblaciones de Legrandia concinna.

\begin{tabular}{|c|c|c|c|c|c|}
\hline \multirow[b]{2}{*}{ Locus } & \multicolumn{5}{|c|}{ Populations } \\
\hline & Radal & La Balsa & Bullileo & $\begin{array}{l}\text { San Fabián de } \\
\text { Alico }\end{array}$ & Minas del Prado \\
\hline \multicolumn{6}{|l|}{$M d h$} \\
\hline 1 & $0.017 \#$ & 0.000 & 0.000 & 0.000 & 0.000 \\
\hline 2 & 0.117 & 1.000 & 1.000 & 1.000 & 1.000 \\
\hline 3 & $0.867 \#$ & 0.000 & 0.000 & 0.000 & 0.000 \\
\hline \multicolumn{6}{|l|}{$M e-1$} \\
\hline 1 & 1.000 & 1.000 & 0.720 & 1.000 & 1.000 \\
\hline 2 & 0.000 & 0.000 & $0.280 \#$ & 0.000 & 0.000 \\
\hline \multicolumn{6}{|l|}{$M e-2$} \\
\hline 1 & 0.000 & 0.000 & 0.063 & 0.054 & 0.000 \\
\hline 2 & 1.000 & 1.000 & 0.938 & 0.946 & 1.000 \\
\hline \multicolumn{6}{|l|}{ Perc-1 } \\
\hline 1 & 0.286 & 0.121 & 0.118 & 0.429 & 0.017 \\
\hline 2 & 0.714 & 0.672 & 0.706 & 0.571 & 0.983 \\
\hline 3 & 0.000 & 0.207 & 0.176 & 0.000 & 0.000 \\
\hline \multicolumn{6}{|l|}{$P g i-1$} \\
\hline 1 & 0.810 & 0.183 & 0.117 & 0.690 & 0.400 \\
\hline 2 & 0.190 & 0.817 & 0.850 & 0.224 & 0.583 \\
\hline 3 & 0.000 & 0.000 & 0.017 & 0.086 & 0.017 \\
\hline 4 & 0.000 & 0.000 & $0.017 \#$ & 0.000 & 0.000 \\
\hline \multicolumn{6}{|l|}{ Skdh } \\
\hline 1 & 0.000 & 0.000 & 0.000 & $0.161 \#$ & 0.000 \\
\hline 2 & 1.000 & 1.000 & 0.983 & 0.839 & 1.000 \\
\hline 3 & 0.000 & 0.000 & $0.017 \#$ & 0.000 & 0.000 \\
\hline
\end{tabular}

\# Unique alleles present in just one population.

\# Alelos únicos presentes en sólo una población.

population size (table 1). Population La Balsa, consisting of more than 2,000 individuals, had relatively reduced isozyme diversity in comparison to that measured in the nearby smaller Bullileo population. Also, this latter population was more genetically diverse than the other similarly small and southernmost population Minas del Prado.

Marked deficiencies of heterozygotes to HardyWeinberg expectations were found in all populations, except Radal at the northern range. The percentage of loci that significantly yielded heterozygous deficiencies, i.e. positive fixation indices, ranged from $33 \%$ at Radal to 50 and $60 \%$ in southern populations (table 3). Similarly, overall significant homozygous excess was shown by the average within-population inbreeding $F_{\text {IS }}=0.395$ (95\% CI $=0.345-0.714$ ) for the entire species.

Total genetic diversity $H_{\mathrm{T}}=0.174$, most of which was distributed within populations $\left(H_{\mathrm{s}}=0.113\right)$. Significant among-population divergence was indicated by $F_{\mathrm{ST}}=$ $0.410(95 \% \mathrm{CI}=0.232-0.705)$. UPGMA cluster analysis shows a clear separation of northern population Radal from the rest located further south which occurred at a genetic distance $>30 \%$ (figure 3). Although not significant, a tendency existed for geographically closer populations to be more genetically similar as shown by a Mantel test of genetic distance against geographic distance $\left(\mathrm{R}^{2}=0.47, P\right.$ $=0.186)$.

\section{DISCUSSION}

Isozyme diversity in the range-restricted $L$. concinna is geographically structured. The significant heterogeneity in allelic frequencies and multivariate analysis suggest the existence of at least two genetically distinct, north and south, clusters within L. concinna. On the other hand, the existence of comparable levels of isozyme diversity, i.e. by means of unbiased $H_{\mathrm{E}}$, even in small (southern population Bullileo) and disjunct (northern population Radal) populations, probably reflect that $L$. concinna consisted of a previously larger and continuous range that became fragmented some time in the past. Climatic changes associated with the last glacial maximum that occurred 
Table 3. Fixation indices for each polymorphic locus and population of Legrandia concinna. Índices de fijación por locus polimórfico y población de Legrandia concinna.

\begin{tabular}{|c|c|c|c|c|c|}
\hline Locus & Radal & La Balsa & Bullileo & $\begin{array}{c}\text { San Fabián de } \\
\text { Alico }\end{array}$ & Minas del Prado \\
\hline$M d h$ & $0.858^{*}$ & - & - & - & - \\
\hline$M e-1$ & - & - & 0.206 & - & - \\
\hline$M e-2$ & - & - & $0.644^{*}$ & $0.648 *$ & - \\
\hline$P g i$ & -0.010 & -0.002 & $0.620 *$ & 0.187 & $0.660^{*}$ \\
\hline Per-1 & -0.400 & $0.648 *$ & $0.485^{*}$ & 0.417 & -0.017 \\
\hline Skdh & - & - & -0.017 & $0.868^{*}$ & - \\
\hline Significance $(\%)^{1}$ & 33 & 50 & 60 & 50 & 50 \\
\hline Mean \pm SE & $0.150 \pm 0.371$ & $0.323 \pm 0.325$ & $0.387 \pm 0.127$ & $0.530 \pm 0.146$ & $0.321 \pm 0.338$ \\
\hline
\end{tabular}

${ }^{1}$ Significance percentage test. *Significant departure from Hardy-Weinberg expectations by Chi-square tests.

${ }^{1}$ Porcentajes de significancia de la prueba. *Desvíos significativos del equilibrio Hardy-Weinberg mediante Chi-cuadrado.

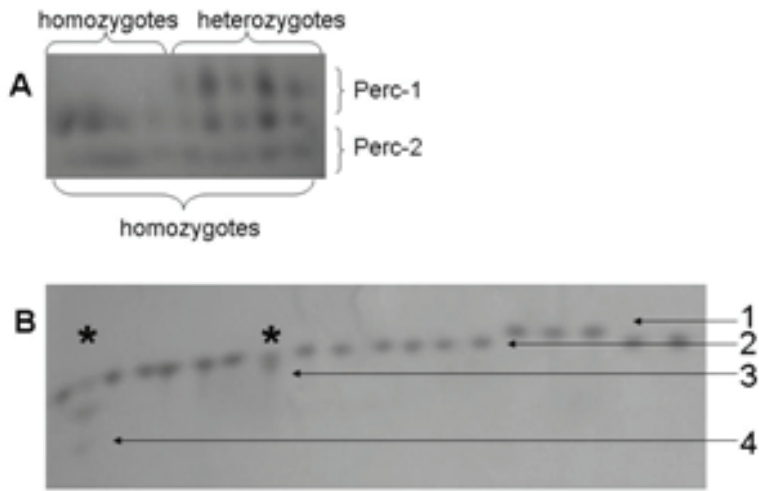

Figure 2. Starch gels of Legrandia concinna. A) Polymorphic (Perc-1) and monomorphic (Per-2) cathodic peroxidase loci, respectively. B) A detail of low-frequency alleles (3 and 4) in heterozygous individuals $(*)$ for the polymorphic phosphoglucoisomerase locus (Pgi-2). Homozygote genotypes have one band; heterozygote individuals depict at least two (monomeric enzyme Perc-1) or three bands (dimeric enzyme Pgi-2).

Geles de almidón de Legrandia concinna. A) Loci polimórfico (Perc-1) y monomórfico (Per-2) de la peroxidasa catódica, respectivamente. B) Un detalle de los alelos de baja frecuencia (3 y 4) en individuos heterocigotos (*) para el locus polimórfico fosfoglucoisomerasa (Pgi-2). Genotipos homocigotos poseen una banda; individuos heterocigotos muestran al menos dos (como la enzima monomérica Perc-1) o tres bandas (como la enzima dimérica Pgi-2).

in Patagonia 18,000 yr BP affected species' distributions restricting their ranges to suitable climates (Markgraf et al. 1995), which has been documented by genetic markers in plant species. In contrast to large scale migrations after the retreat of glaciers from refugia in warmer locations described for North America and Europe, the presence of multiple centers of genetic diversity in plant taxa suggests that species survived locally in Chile (Premoli et al. 2000, Bekessy et al. 2002, Mullener et al. 2004). Therefore, genetically diverse and latitudinally distinguished groups of populations may indicate distinct glacial refugia for

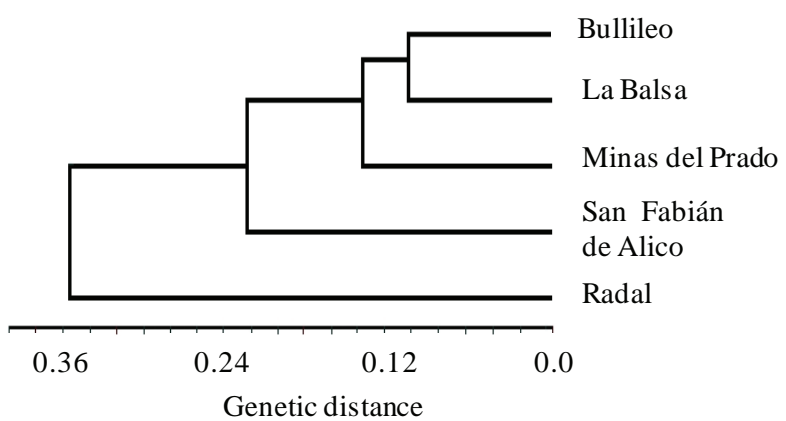

Figure 3. Dendrogram showing clustering of populations of Legrandia concinna based on the modified Rogers genetic distance. Dendrograma del agrupamiento de poblaciones de Legrandia concinna con base en la distancia genética modificada de Rogers.

\section{L. concinna.}

Significant average inbreeding may be due to selfing, vegetative spread, and intrapopulation Wahlund effect by local seedling establishment. Multilocus average outcrossing rate of Luma apiculata, a Myrtaceae endemic to austral forests of Argentina and Chile, was $t=0.65$ suggesting that has a mixed mating system and therefore selfing can occur (Caldiz and Premoli 2005). Similarly, total within-population inbreeding of Luma apiculata $\left(F_{\text {IS }}=0.480,95 \%\right.$; CI $\left.=0.383-0.561\right)$ was within the range estimated here for $L$. concinna $\left(F_{\text {IS }}=0.395,95\right.$ $\%$; CI $=0.345-0.714$ ) suggesting similar reproductive systems. As in other Myrtaceae, pollination of L concinna is mainly entomophyllous and thus pollinator behavior may only reach small distances which may prevent outcrossing (Hingston and Potts 1998, McDonald et al. 2003). Germination of $L$. concinna seeds is almost 50 $\%$ under experimental conditions (Gardner et al. 2006) and seedlings in the field are rarely seen ${ }^{1}$. This may be interpreted as a reduction in progeny fitness derived from

\footnotetext{
${ }^{1}$ Camila Martínez: personal observation.
} 
inbreeding (Husband and Schemske 1996). Inbreeding depression is caused by increased homozygosity of individuals, which is detectable by the lower fertility, survival, and growth rates of individuals with high inbreeding coefficients (Charlesworth and Willis 2009). However, inbreeding depression should increase within recently inbred populations because deleterious recessive mutations with large effect become exposed in homozygous genotypes and not enough time has elapsed to be effectively purged by selection. Although more studies are needed on the mating system and fitness traits of progeny in fragmented landscapes (e.g. Mathiasen et al. 2007), potential negative effects of inbreeding and genetic impoverishment due to vegetative propagation should be considered in demographic recovery and conservation practices of $L$. concinna.

Overall reduced within-population inbreeding was found in northern-most population Radal. This population is geographically isolated from the rest populations further south and therefore higher inbreeding was expected. This population is crossed by small creeks, and thus, influx of seeds received from other nearby populations may counteract the effects of genetic drift, which results in elevated heterozygosity and reduced inbreeding.

Legrandia concinna has slightly lower total diversity $\left(H_{\mathrm{T}}=0.174\right)$ in comparison with Luma apiculata $\left(H_{\mathrm{T}}=\right.$ 0.259, Caldiz and Premoli 2005) another Myrtaceae endemic to Patagonia with a wider distributional range. However, the genetic divergence among $L$ concinna populations $\left(F_{\mathrm{ST}}=0.410,95 \%\right.$; $\left.\mathrm{CI}=0.232-0.705\right)$ is fivefold and significantly greater than among Luma apiculata populations $\left(G_{\mathrm{ST}} \sim F_{\mathrm{ST}}=0.085,95 \%\right.$; CI $=$ 0.055 - 0.098) despite the restricted latitudinal distribution of the former (100 vs. $500 \mathrm{~km}$ in L. Concinna and Luma apiculata, respectively). Reduced genetic diversity and marked among-population divergence was recorded in other two rare range-restricted eucalypts. Eucalyptus pulverulenta Sims. consists of only eight populations with disjunct distribution in south-eastern Australia $\left(H_{\mathrm{T}}=0.10\right.$, $H_{\mathrm{S}}=0.07, G_{\mathrm{ST}}=30 \%$, Peters et al. 1990) and E. caesia Benth. occurs in 15 populations restricted to granite rocks in south-western Australia $\left(H_{\mathrm{T}}=0.176, H_{\mathrm{S}}=0.068, G_{\mathrm{ST}}\right.$ $=61 \%$, Moran and Hopper 1983). These results suggest that genetic drift and long term population isolation may have been responsible for the low overall genetic diversity and the extensive population differentiation within rare Myrtaceae.

High $F_{\mathrm{ST}}$ levels in L. concinna reflect restrictions for among-population gene flow. This is probably due to the fact that native forest populations are immersed into a matrix with exotic pine ( $P$. radiata) plantations that may prevent genetic exchange among populations. More in-depth studies are needed including the use of other genetic markers, adaptive traits, and demographic information to assure the long term viability of $L$. concinna populations. This is particularly critical in the face of the construction of hydroelectric dams within $L$. concinna's range. Nevertheless, the data presented here shows that urgent actions are needed to preserve the gene pool of L. concinna, which in turn is not included within any protected area. Recent studies have demonstrated high rates of deforestation and fragmentation in the study area (Altamirano and Lara 2010) and in the Coastal Range of Maule Region (Echeverría et al. 2006). These studies have also shown the replacement of native forest by commercial plantations of exotic species and the need to promote connectivity of native forests at landscape level.

Conservation actions should be taken to protect reservoirs of genetic diversity such as elevated polymorphism and heterozygosity of small and disjunct populations as Bullileo and Radal. These two populations are under a severe threat because they are in the vicinity of touristic areas (camping sites) and pastures for cattle. Possible harmful effects of inbreeding should be analyzed in southern populations, especially population Minas del Prado that has been heavily fragmented for agricultural purposes and later surrounded by dense forest plantations. Also, recovery of the common knowledge on this plant and dissemination of its conservation needs are urgent to produce a better commitment from the people that live and work in areas where L. concinna grows.

\section{ACKNOWLEDGEMENTS}

Authors thank Paula Quiroga and Cintia Souto for their valuable assistance in the laboratory. We also would like to acknowledge the contribution to this work to Diego Alarcón, Martin Gardner, Leslie Landrum, Carlos Le Quesne, and the valuable assistance provided by the Herbario de Concepcion and CONAF (Corporación Nacional Forestal). This research was funded by the European Commission under Framework IV of DGXII, as part of the BIOCORES project (PL ICA4-2000-10029) and Darwin Initiative Project (DEFRA-U.K.; Project 162/11/012) "An integrated conservation program for threatened, endemic forest species in Chile”.

\section{REFERENCES}

Altamirano A, A Lara. 2010. Deforestación en ecosistemas templados de la precordillera andina del centro-sur de Chile. Bosque 31(1):53-64.

Armesto J, C Smith-Ramírez, P León. 1992. Biodiversidad y conservación del bosque templado en Chile. Ambiente y Desarrollo 8:19-24.

Armesto J, P Leon-Lobos, MK Arroyo. 1995. Los bosques templados del sur de Chile y Argentina: una isla biogeográfica. In Armesto J, C Villagrán, MK Arroyo eds. Ecología de los Bosques Nativos de Chile. Santiago, Chile. Editorial Universitaria. p. 23-28.

Bekessy SA, TR Allnutt, AC Premoli, A Lara, RA Ennos, MA Burgman, M Cortes, AC Newton. 2002. Genetic variation in the vulnerable and endemic Monkey Puzzle tree, detected 
using RAPDs. Heredity 88:243-249.

Benoit I. 1989. Libro rojo de la flora terrestre de Chile. Santiago, Chile. CONAF (Corporacion Nacional Forestal, CL). 157 p.

Berg EE, JL Hamrick. 1997. Quantification of genetic diversity at allozyme loci. Canadian Journal of Forest Research 27: 415-424.

Brook BW, DW Tonkyn, JJ O'Grady, R Frankham. 2002. Contribution of inbreeding to extinction risk in threatened species. Conservation Ecology 6:1-16.

Caldiz MS, AC Premoli. 2005. Isozyme diversity in large and isolated populations of Luma apiculata (Myrtaceae) in north-western Patagonia, Argentina. Australian Journal of Botany 53:781-787.

Charlesworth D, JH Willis. 2009. The genetics of inbreeding depression. Nature Reviews 10:783-796.

Conkle MT, PD Hodgskiss, LB Nunnally, SC Hunter. 1982. Starch gel electrophoresis of pine seeds: a laboratory manual. Berkeley, California. United States Department of Agriculture. $18 \mathrm{p}$.

Donoso C. 1993. Estructura y dinámica de los bosques dominados por las especies de Nothofagus. In Donoso C ed. Bosques templados de Chile y Argentina; Variación, estructura y dinámica. Santiago, Chile. Editorial Universitaria. p. 303322.

Echeverria C, D Coomes, J Salas, JM Rey-Benayas, A Lara, A Newton. 2006. Rapid deforestation and fragmentation of chilean temperate forests. Biological Conservation 130:481-494.

Frankham R, DA Briscoe, JD Ballou. 2002. Introduction to conservation genetics. New York, USA. Cambridge University Press. 617 p.

Gardner MF, P Hechenleitner, PI Thomas, C Echeverría, B Escobar, P Brownless, C Martínez. 2006. Threatened Plants of Central and South Chile: Distribution, conservation and propagation. Edinburgh, Great Britain. RBG Edinburgh. $188 \mathrm{p}$.

Goudet J. 2000. FSTAT: A program to estimate and test gene diversities and fixation indices. Release 2.9.1. Université de Lausanne. Consulted 9 may. 2005. Available in http://. www2.unil.ch/popgen/softwares/fstat.htm.

Hartl DL, AG Clark. 2007. Principles of population genetics. Fourth edition. Sunderland, MA, USA. Sinauer. 565 p.

Hingston AB, BM Potts. 1998. Floral visitors of Eucalyptus globulus subsp. globulus in eastern Tasmania. Tasforests 10:125-139.

Husband BC, DW Schemske. 1996. Evolution of the Magnitude and Timing of Inbreeding Depression in Plants. Evolution 50: 54-70.

King JN, BP Dancik. 1983. Inheritance and linkage of isozymes in white spruce (Picea glauca). Canadian Journal of Genetics and Cytology 25:430-436.

Landrum LR. 1986. A Monograph of the Genus Campomanesia, Pimenta, Blepharocalyx, Legrandia, Acca, Myrrhinium, and Luma (Myrtaceae). Flora Neotrópica 45:1-173.

Li CC, DG Horvitz. 1953. Some methods of estimating the inbreeding coefficient. American Journal of Human Genetics 5:107-117.

Markgraf V, M McGlone, G Hope. 1995. Neogene paleoenvironmental and paleoclimatic change in southern temperate ecosystems - a southern perspective. TREE $10: 143-147$
Mantel N. 1967. The detection of disease clustering as a generalized regression approach. Cancer Research 27:209220.

Mathiasen P, AE Rovere, AC Premoli. 2007. Genetic structure and early acting effects of inbreeding in fragmented temperate forests of a self-incompatible tree, Embothrium coccineum. Conservation Biology 21: 232-240.

McDonald MW, M Rawlings, PA Butcher, JC Bell. 2003. Regional divergence and inbreeding in Eucalyptus cladocalyx (Myrtaceae). Australian Journal of Botany 51:393-403.

Mitton JB, YB Linhart, KB Sturgeon, JL Hamrick. 1979. Allozyme polymorphisms detected in mature needle tissue of ponderosa pine. Journal of Heredity 70:86-89.

Moran GF, SD Hopper. 1983. Genetic diversity and the insular population structure of the rare granite rock species, Eucalyptus caesia Benth. Australian Journal of Botany 31:161-172.

Muellener AN, K Tremetsberger, T Stuessy, CM Baeza. 2004. Pleistocene refugia and recolonization routes in the southern Andes: insights from Hypochaeris palustris (Asteraceae, Lactuceae). Molecular Ecology 14:203-212.

Myers N, RA Mittermeier, CG Mittermeier, GAB Da Fonseca, J Kent. 2000. Biodiversity hotspots for conservation priorities. Nature 403:853-858.

Nei M. 1973. Analysis of gene diversity in subdivided populations. Proceedings of the National Academy of Sciences 70:3321-3323.

Nei M. 1978. Estimation of average heterozygosity and genetic distance from a small number of individuals. Genetics 89:583-590.

Neira E, H Verscheure, C Revenga. 2002. Chile's frontier forests: conserving a global treasure. Washington DC, USA. WRI (World Resources Institute, USA), CODEFF (Comité pro Defensa de la Fauna y Flora, CL) and UACh (Universidad Austral de Chile, CL). 57 p.

Peters GB, JS Lonie, GF Moran. 1990. The breeding system, genetic diversity and pollen sterility in Eucalyptus pulverulenta, a rare species with small disjunct populations. Australian Journal of Botany 38:559-570.

Premoli AC, T Kitzberger, TT Veblen. 2000. Isozyme variation and recent biogeographical history of the long-lived conifer Fitzroya cupressoides. Journal of Biogeography 27:251260.

Rogers JS. 1972. Measures of genetic similarity and genetic distances. Studies in Genetics VII. University of Texas publication 7213:145-153.

Serra MT, R Gajardo, A Cabello. 1986. Legrandia concinna (Phil.) Programa de protección y recuperación de la flora nativa de Chile. Ficha técnica de especies amenazadas. Santiago, Chile. Corporación Nacional Forestal (CONAF). 20p.

Spielman D, BW Brook, R Frankham. 2004. Most species are not driven to extinction before genetic factors impact them. Proceeding of the Natural Academy of Sciences 101:1526115264.

Torres-Díaz C, E Ruiz, F González, G Fuentes, LA Cavieres. 2007. Genetic diversity in Nothofagus alessandrii (Fagaceae), an endangered endemic tree species of the Coastal Maulino Forest of Central Chile. Annals of Botany 100:75-82. 
Villagrán C, C Le-Quesne. 1996. El Interés biogeográficohistórico de Chile Central-Sur: ¿Por qué Debemos Conservar su Biota? In Muñoz M, H Núñez, J Yañez eds. Libro Rojo de los Sitios Prioritarios para la conservación de la diversidad biológica en Chile. Santiago, Chile. Corporación Nacional Forestal. p. 160-172.

Walter KS, HJ Gillet. 1998. 1997 IUCN Red List of threatened plants. Gland, Switzerland. IUCN- The world conservation union. $862 \mathrm{p}$.

Yeh FC, RC Yang, T Boyle, ZH Ye, JX Mao. 1997. POPGENE, the user-friendly shareware for population genetic analysis. Molecular Biology and Biotechnology Centre, University of Alberta. Consulted 15 aug. 2003. Available at http://www.ualberta.ca/ fyeh/.

Recibido: 23.07.10

Aceptado: 16.11 .10 